\title{
Anita Perska-Tembłowska
}

Uniwersytet Ekonomiczny w Poznaniu

e-mail: anita.perska@ue.poznan.pl

\section{WSPÓŁDZIAŁANIE PRZY FORMUŁOWANIU \\ CELÓW STRATEGICZNYCH \\ NA PRZYKŁADZIE OBSZARU FUNKCJONALNEGO \\ AGLOMERACJI LESZCZYŃSKIEJ \\ COOPERATION IN SETTING GOALS \\ ON THE EXAMPLE OF THE FUNCTIONAL AREA \\ OF LESZNO AGGLOMERATION}

DOI: $10.15611 /$ pn.2018.538.26

JEL Classification: H70, R58

Streszczenie: Formułowanie strategii rozwoju gminy stanowi wieloetapowy proces, w który zaangażowane są różne podmioty i jednostki, w większości zlokalizowane na terenie danej gminy. Jeszcze większym wyzwaniem w zakresie organizacji i zarządzania jest formułowanie strategii rozwoju dla obszaru obejmującego gminy, które charakteryzują się wspólnymi uwarunkowaniami geograficznymi, społeczno-gospodarczymi, systemem powiązań funkcjonalnych. Wówczas następuje konieczność podjęcia dialogu między interesariuszami tych gmin. Głównym celem artykułu była identyfikacja interesariuszy zaangażowanych w proces wyboru celów strategicznych zawartych w Strategii Rozwoju Społeczno-Gospodarczego Obszaru Funkcjonalnego Aglomeracji Leszczyńskiej do 2030 roku. Wskazane zostały mechanizmy współdziałania oraz stosowane narzędzia mające na celu rozpoznanie potrzeb i oczekiwań interesariuszy gmin. W artykule wykorzystano informacje pozyskane w trakcie wywiadu pogłębionego oraz dokonano analizy literatury i materiałów źródłowych.

Słowa kluczowe: cele strategiczne, strategia rozwoju lokalnego, współzarządzanie, współdziałanie, obszar funkcjonalny.

Summary: The commune's strategy formulation process is a multi-stage process in which various entities and individuals are involved. An even greater challenge in terms of organization and management is the formulation of development strategies for the area including communes that are characterized by common geographical and socio-economic determinants as well as a system of functional links. Then, there is a need for a dialogue between the municipalities' stakeholders of these communes. The main aim of the article was to identify stakeholders involved in the process of setting strategic goals included in the Strategy for Socio-Economic Development of the Functional Area of Leszno Agglomeration until 2030. Co-operation mechanisms and tools used to identify the needs and expectations 
of local stakeholders were indicated. An in-depth interview was conducted as well as the literature and source materials were analyzed.

Keywords: strategic goals, strategy of local development, governance, cooperation, functional area.

\section{Wstęp}

W polskiej literaturze proces budowania strategii rozwoju gmin stanowił przedmiot zainteresowań badaczy na początku XXI wieku. Pod wpływem różnych procesów i zjawisk zmieniły się uwarunkowania funkcjonowania gmin. Rosnąca konkurencja gmin o mieszkańców i inwestorów, wzrastające oczekiwania co do jakości usług publicznych, problemy demograficzne i środowiskowe stały się wyzwaniami, z jakimi mierzyły się gminy w ostatnich latach. Obserwowano przenikanie się elementów typowych dla obecnych w wielu innych państwach koncepcji: New Public Management (nowe zarządzanie publiczne) i Public Governance (współzarządzanie). Rozpoczęła się również dyskusja nad potrzebą wykorzystania potencjałów terytoriów określonych funkcjonalnie, co obok integracji działań publicznych w wymiarze przestrzennym i wielopoziomowym systemem zarządzania stanowi jeden z przejawów zintegrowanego podejścia terytorialnego.

Badacze najwięcej uwagi poświęcają procesowi zarządzania strategicznego w obszarach metropolitalnych, mniej natomiast innym rodzajom obszarów. W artykule analizą objęto obszar subregionalny na przykładzie aglomeracji leszczyńskiej. Problem badawczy w postaci pytania brzmiał następująco: jacy interesariusze i w jaki sposób zostali zaangażowani w proces wyboru celów strategicznych zawartych w Strategii Rozwoju Społeczno-Gospodarczego Obszaru Funkcjonalnego Aglomeracji Leszczyńskiej do 2030 roku? Cel badawczy obejmował identyfikację podmiotów biorących udział przy ustalaniu celów strategicznych oraz wskazanie mechanizmów współdziałania i stosowanych narzędzi mających na celu rozpoznanie potrzeb i oczekiwań tych podmiotów. W opisie wykorzystano informacje pozyskane w trakcie wywiadu pogłębionego z pracownikiem Urzędu Miasta Leszna, w tym odniesiono się do doświadczeń nabytych przy formułowaniu i aktualizacji strategii rozwoju tego miasta. Wywiad zrealizowano w ramach projektu badawczego pt. Uwarunkowania i kryteria wyboru celów strategicznych gmin w perspektywie wspótzarzadzania ${ }^{1}$ (działanie zostało sfinansowane przez Narodowe Centrum Nauki w konkursie Miniatura 1, nr rej. wniosku 2017/01/X/HS4/01878). Ponadto przeprowadzono analizę dokumentu Strategia Rozwoju Społeczno-Gospodarczego Obszaru Funkcjonalnego Aglomeracji Leszczyńskiej do 2030 roku w przedmiotowym zakresie artykułu.

${ }^{1}$ Badaniem objęto 40 gmin. Wywiady pogłębione zostały przeprowadzone od lipca do listopada 2018 r. 


\section{Strategie rozwoju gmin w kontekście wybranych koncepcji}

O ile podstawy zarządzania strategicznego pochodzą z sektora prywatnego, o tyle są również wykorzystywane w sektorze publicznym. Myślenie strategiczne coraz częściej jest obecne u osób zarządzających gminami, czego potwierdzeniem jest budowanie i wdrażanie strategii rozwoju gmin. Formułowanie strategii rozwoju gmin można uznać za przejaw koncepcji nowego zarządzania publicznego (New Public Management), które charakteryzowało przejmowanie narzędzi z sektora prywatnego [Zawicki 2013, s. 17, 54-79; Lachiewicz, Walecka 2013, s. 66-67; Kulesza, Sześciło 2013, s. 79-93; Gawroński 2010, s. 42-43]. Pomimo że w Polsce nie wprowadzono reform nowego zarządzania publicznego, obserwuje się korzystanie z jego instrumentarium przez samorząd lokalny [Zawicki 2011, s. 123].

Równocześnie następuje rozwój innych koncepcji zarządzania publicznego. Istotną koncepcją w kontekście podejmowanego tematu jest współzarządzanie (Public Governance). Skupienie następuje na rozwoju procedur partycypacyjnych i konsultacji z interesariuszami [Zawicki 2011, s. 17; Gawroński 2010, s. 46]. Interesariusze to grupy, instytucje i organizacje, które spełniają dwa warunki - mają swoją ,stawkę” w działaniu danej organizacji, jej decyzjach i ich efektach (1) oraz są w stanie wywrzeć presję na tę organizację (2) [Obłój 2014, s. 187]. Podkreśla się, że zarządzanie w sektorze publicznym nie może opierać się wprost na biznesowych wzorcach, lecz na współdziałaniu różnych organizacji [Lachiewicz, Walecka 2013, s. 67]. W modelu współzarządzania administracja publiczna dostrzega mieszkańca, przedsiębiorcę, podmioty, dla służenia którym została powołana [Anders-Morawska, Rudolf 2015, s. 36]. W polskiej praktyce zidentyfikować można przykłady praktycznego zastosowania koncepcji governance, m.in. konsultacje społeczne, tworzenie rad i zespołów z udziałem przedstawicieli różnych instytucji, budżet partycypacyjny [Kulesza, Sześciło 2013, s. 120]. Do angażowania interesariuszy w proces podejmowania decyzji nawiązuje również koncepcja zarządzania wielopoziomowego (Multi-Level Governance). Za wartości przyjmuje się: współpracę, kreowanie poczucia wspólnego celu, poszukiwanie kompromisu, opieranie relacji na zaufaniu [Flieger 2016, s. 122-124].

$\mathrm{W}$ organizacjach publicznych proces podejmowania decyzji cechuje niższy poziom racjonalności niż $\mathrm{w}$ organizacjach prywatnych, a znaczenia nabiera kontekst otoczenia i pozycja interesariuszy [Frączkiewicz-Wronka 2012, s. 24]. Istotne jest, aby przy formułowaniu strategicznych założeń uwzględnić nie tylko wnętrze jednostki (identyfikacja mocnych i słabych stron), lecz także jej otoczenie (identyfikacja szans i zagrożeń) [Bryson 2004, s. 33; Bryson, Alston 2005, s. 77-83]. Przetrwanie organizacji następuje tylko wtedy, gdy spełniają one wymogi narzucone przez otoczenie, które sankcjonuje ich działania, ponieważ wówczas mogą pozyskać z otoczenia potrzebne zasoby [Cyfert, Krzakiewicz 2018, s. 52]. 


\section{Partnerstwo obszaru funkcjonalnego aglomeracji leszczyńskiej}

Leszno to miasto na prawach powiatu położone w województwie wielkopolskim, pomiędzy dwoma silnymi centrami gospodarczymi - Poznaniem i Wrocławiem. Według Głównego Urzędu Statystycznego na dzień 31.12.2017 r. Leszno zamieszkiwało 64197 osób, plasując miasto na miejscu 7. pod względem liczby ludności w Wielkopolsce i 63. w Polsce.

Na podstawie zapisów Koncepcji Przestrzennego Zagospodarowania Kraju 2030 [2011, s. 181] można przyjąć, że Leszno stanowi miejski obszar funkcjonalny o typie ośrodka subregionalnego (>50 tys.). Miasto uczestniczyło w projekcie wspierającym rozwój obszarów funkcjonalnych pt. Partnerstwo Obszaru Funkcjonalnego dla wzmocnienia rozwoju spójności spoleczno-gospodarczej Aglomeracji Leszczyńskiej, współfinansowanym z funduszy EOG 2009-2014, pochodzących z Islandii, Liechtensteinu i Norwegii, oraz ze środków krajowych. Projekt trwał od 1.02.2014 r. do 31.03.2016 r. Razem z miastem Lesznem (lider) w projekcie uczestniczyły: powiat leszczyński, gmina Krzemieniewo, gmina Lipno, gmina Osieczna, gmina Rydzyna, gmina Święciechowa, gmina Wijewo, gmina Włoszakowice, gmina Przemęt ${ }^{2}$ (rys. 1). Oprócz jednostek samorządu terytorialnego w projekcie uczestniczyli partnerzy: Państwowa Wyższa Szkoła Zawodowa w Lesznie, Leszczyńskie Centrum Biznesu

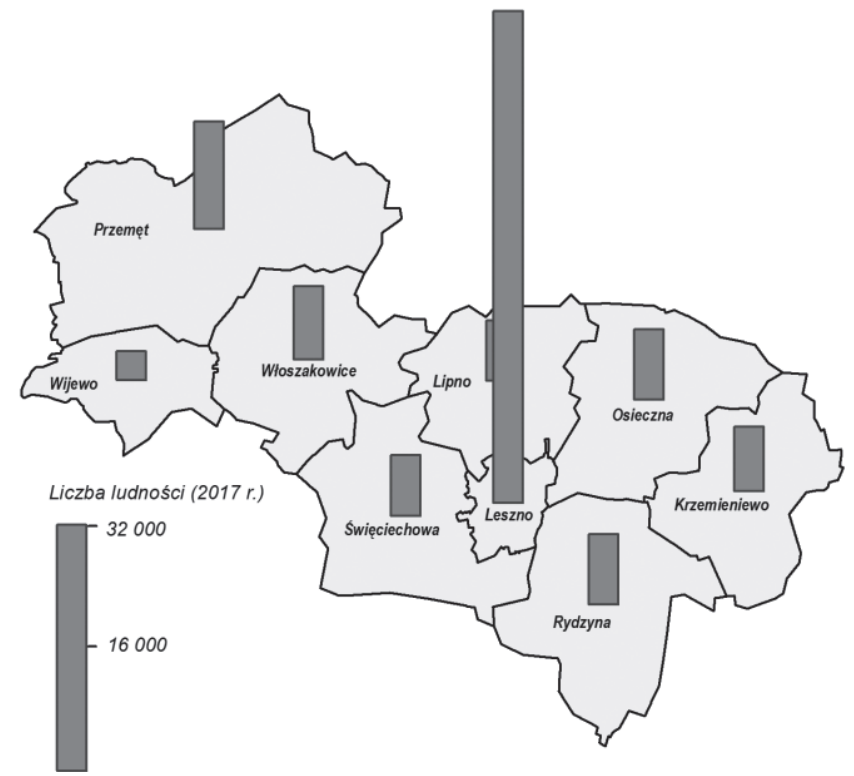

Rys. 1. Liczba mieszkańców obszaru funkcjonalnego aglomeracji leszczyńskiej

Źródło: opracowanie własne na podstawie danych GUS BDL.

${ }^{2}$ Gmina Przemęt położona jest w powiecie wolsztyńskim, pozostałe gminy w powiecie leszczyńskim. 
Sp. z o.o., Regionalna Izba Przemysłowo-Handlowa, Organizacja Turystyczna Leszno-Region [Potkański, Wiktorczyk-Nadolna (red.) 2016, s. 24].

Zintegrowane podejście do rozwoju analizowanego obszaru zostało potwierdzone podczas identyfikacji problemów i możliwości rozwoju, w tym podczas opracowywania w ramach projektu dokumentów strategicznych, m.in. Strategii Rozwoju Społeczno-Gospodarczego Obszaru Funkcjonalnego Aglomeracji Leszczyńskiej do 2030 roku. Ponadto sporządzono dokumentację techniczną dla przedsięwzięć inwestycyjnych wynikających z dokumentów strategicznych [Potkański, Wiktorczyk-Nadolna (red.) 2016, s. 24-25].

\section{Współdziałanie przy wyborze celów strategicznych obszaru funkcjonalnego aglomeracji leszczyńskiej}

Strategia Społeczno-Gospodarczego Obszaru Funkcjonalnego Aglomeracji Leszczyńskiej do 2030 roku obejmuje następujące jednostki terytorialne: miasto Leszno, gminy: Krzemieniewo, Lipno, Osieczna, Rydzyna, Święciechowa, Wijewo, Włoszakowice, Przemęt oraz powiat leszczyński [Strategia 2014, s. 8]. W dokumencie podano, że strategia jest rezultatem współpracy samorządów obszaru z ekspertami zewnętrznymi, przy uwzględnieniu konsultacji i partycypacji społecznej [Strategia 2014, s. 9].

Proces budowania strategii obszaru funkcjonalnego rozpoczął się od przeprowadzenia diagnozy poprzedzającej część planistyczną dokumentu, a następnie sformułowano zapisy strategii - wizję, cele rozwoju i zadania strategiczne. Na etapie tworzenia dokumentu istniała możliwość wniesienia uwag i pomysłów przez społeczeństwo [Strategia 2014, s. 14]. Według relacji respondenta miasto Leszno podobne podejście wykorzystywało przy aktualizacji strategii rozwoju miasta - zorganizowane były grupy robocze, do których zaproszeni zostali urzędnicy, mieszkańcy, przedstawiciele organizacji pozarządowych i podmiotów gospodarczych, a także liderzy lokalni. Ponadto już w latach 90 . XX wieku, podczas formułowania pierwszej strategii rozwoju miasta, współpracowano z grupą naukowców z ówczesnej Akademii Ekonomicznej w Poznaniu.

Przy formułowaniu Strategii Społeczno-Gospodarczego Obszaru Funkcjonalnego Aglomeracji Leszczyńskiej zaangażowanie mieszkańców, organizacji pozarządowych i partnerów przebiegało wielotorowo. Po pierwsze, interesariusze byli zaangażowani w formułowanie diagnozy, która poprzedzała część planistyczną strategii (badanie ankietowe społeczności lokalnej, uczestnictwo w warsztatach planowania strategicznego). Po drugie, uzgadniano zapisy dokumentu strategicznego (w tym m.in. sformułowanie wizji, celów rozwoju i przedsięwzięć), przeprowadzając badania preferencji i potrzeb mieszkańców (badanie ankietowe, wywiady, uczestnictwo w warsztatach planowania strategicznego i spotkaniach konsultacyjnych) [Strategia 2014, s. 14].

Celem przeprowadzonego badania społeczności lokalnych było poznanie opinii mieszkańców o warunkach życia na obszarze objętym strategią i oczekiwań w zakresie kierunków rozwoju obszaru. Zgromadzony materiał badawczy posłużył opracowaniu 
diagnozy stanu społeczno-gospodarczego obszaru i strategii rozwoju. Wykorzystano trzy techniki badawcze: wywiady bezpośrednie kwestionariuszowe (PAPI), indywidualne wywiady pogłębione (IDI) i ankiety internetowe (CAWI) [Strategia 2014, s. 14-16].

Wywiady pogłębione były realizowane od maja do czerwca 2014 r. w jednostkach terytorialnych wchodzących w skład obszaru funkcjonalnego aglomeracji leszczyńskiej (tab. 1). Łącznie zostało przeprowadzonych 600 wywiadów. Próba została dobrana w sposób proporcjonalny do udziału mieszkańców danej jednostki terytorialnej w liczbie osób zamieszkujących obszar aglomeracji leszczyńskiej [Strategia 2014, s. 14-15].

Uzupełnieniem badania PAPI była technika CAWI, polegająca na umieszczeniu kwestionariusza ankietowego na stronie internetowej http://www.leszno.pl. Opinie zbierano w czerwcu 2014 r., a kwestionariusz wypełniło łącznie 8 osób (tab. 1) [Strategia 2014, s. 15].

Z kolei wywiady zostały przeprowadzone z opiniotwórczymi przedstawicielami społeczności lokalnych aglomeracji leszczyńskiej: kierownikami jednostek samorządowych z partnerstwa oraz radnymi, przedsiębiorcami, przedstawicielami ośrodków kultury, ośrodków edukacji, przedstawicielami organizacji pozarządowych, przedstawicielami jednostek samorządu terytorialnego, przedstawicielami ośrodków pomocy społecznej, służb zatrudnienia [Strategia 2014, s. 16]. Od maja do czerwca 2014 r. przeprowadzono łącznie 63 wywiady, dzięki którym uzyskano konkretne informacje według przygotowanego scenariusza wywiadu (tab. 1). Wywiady były nagrywane, a następnie zostały sporządzone transkrypcje. Podczas wywiadów dążono do pogłębiania zagadnień i wyjaśnienia zidentyfikowanych zjawisk (dlaczego dane zjawisko występuje) [Strategia 2014, s. 15-16].

Tabela 1. Liczba respondentów biorących udział w badaniu społeczności lokalnej

\begin{tabular}{|l|c|c|c|}
\hline \multirow{2}{*}{\multicolumn{1}{|c|}{ Gminy }} & PAPI & CAWI & IDI \\
\cline { 2 - 4 } & maj-czerwiec 2014 & czerwiec 2014 & maj-czerwiec 2014 \\
\hline Leszno (miasto) & 294 & 2 & 14 \\
\hline Krzemieniewo (gmina wiejska) & 39 & 1 & 6 \\
\hline Lipno (gmina wiejska) & 32 & & 7 \\
\hline Osieczna (gmina miejsko-wiejska) & 41 & & 6 \\
\hline Rydzyna (gmina miejsko-wiejska) & 39 & 1 & 6 \\
\hline Święciechowa (gmina wiejska) & 34 & 2 & 7 \\
\hline Wijewo (gmina wiejska) & 17 & 1 & 6 \\
\hline Włoszakowice (gmina wiejska) & 41 & 1 & 6 \\
\hline Przemęt (gmina wiejska) & 63 & & 63 \\
\hline & 600 & 8 & 6 \\
\hline
\end{tabular}

Źródło: opracowanie własne na podstawie [Strategia 2014, s. 14-16]. 
W sierpniu 2014 r. zorganizowane zostały warsztaty dla Rady Partnerstwa (wójtowie, burmistrzowie, prezydent, starosta) i dla zespołów roboczych: zespołu do spraw technicznych, zespołu do spraw infrastruktury technicznej, zespołu do spraw gospodarki (tab. 2). Członkami zespołów zostali pracownicy urzędów gmin i jednostek organizacyjnych, reprezentanci starostwa powiatowego, radni, przedstawiciele sektora prywatnego i pozarządowego, a także środowiska naukowego. Na etapie przygotowania dokumentu spotkania o charakterze warsztatów każdej z grup roboczych odbyły się dwukrotnie. Zakres warsztatów obejmował m.in. analizę SWOT oraz wyznaczenie celów strategicznych i zadań strategicznych [Strategia 2014, s. 9]. Podczas przeprowadzonego wywiadu reprezentant Urzędu Miasta Leszna wskazał, że wybór celów strategicznych miasta Leszna nastąpił również na podstawie analizy SWOT, podkreślając objęcie analizą wnętrza miasta i jego otoczenia.

Tabela 2. Reprezentanci instytucji należący do zespołów roboczych według lokalizacji instytucji

\begin{tabular}{|l|c|c|c|}
\hline \multirow{2}{*}{$\begin{array}{c}\text { Reprezentanci } \\
\text { instytucji }\end{array}$} & $\begin{array}{c}\text { Zespół do spraw } \\
\text { gospodarki }\end{array}$ & $\begin{array}{c}\text { Zespół do spraw infrastruktury } \\
\text { technicznej }\end{array}$ & $\begin{array}{c}\text { Zespół do spraw } \\
\text { społecznych }\end{array}$ \\
\cline { 2 - 4 } & 11 i 18.08.2014 & 12 i 19.08.2014 & 13 i 20.08.2014 \\
\hline Leszno & 28 & 22 & 25 \\
\hline Krzemieniewo & 3 & 3 & 3 \\
\hline Lipno & 2 & 2 & 2 \\
\hline Osieczna & 1 & 2 & 4 \\
\hline Rydzyna & 2 & 2 & 3 \\
\hline Święciechowa & 2 & 2 & 2 \\
\hline Wijewo & 3 & 2 & 3 \\
\hline Włoszakowice & 2 & 2 & 45 \\
\hline Przemęt & 2 & 37 & 2 \\
\hline & 45 & 2 & 2 \\
\hline
\end{tabular}

Źródło: opracowanie własne na podstawie listy osób biorących udział w warsztatach zespołów roboczych [Strategia 2014, s. 9-13].

W warsztatach uczestniczyli eksperci w zakresie poszczególnych obszarów tematycznych (tab. 3). W trakcie wywiadu reprezentant Leszna wskazał, że podczas przygotowywania strategii rozwoju miasta grupy robocze tworzone były również pod względem obszarów tematycznych.

Wypracowane podczas warsztatów założenia zostały zweryfikowane w trakcie otwartych konsultacji społecznych z udziałem przedstawicieli społeczności obszaru funkcjonalnego aglomeracji leszczyńskiej. Konsultacje odbyły się w dniu 8.09.2014 r. w siedzibie Leszczyńskiego Centrum Biznesu Sp. z o.o. w Lesznie i uczestniczyło w nich 30 osób. W trakcie spotkania dyskutowano nad konkretnymi zapisami, zbierano uwagi i rozważano propozycje modyfikacji niektórych zapisów. Projekt Strategii został zamieszczony na stronie internetowej Leszna [Strategia 2014, s. 16]. 
Tabela 3. Reprezentanci instytucji należący do zespołów roboczych według rodzaju instytucji

\begin{tabular}{|c|c|c|c|}
\hline \multirow[t]{2}{*}{ Reprezentanci instytucji } & $\begin{array}{l}\text { Zespół do spraw } \\
\text { gospodarki }\end{array}$ & $\begin{array}{l}\text { Zespół do spraw } \\
\text { infrastruktury } \\
\text { technicznej }\end{array}$ & $\begin{array}{l}\text { Zespół do spraw } \\
\text { społecznych }\end{array}$ \\
\hline & 11 i 18.08 .2014 & 12 i 19.08 .2014 & 13 i 20.08 .2014 \\
\hline $\begin{array}{l}\text { Pracownicy urzędów } \\
\text { i jednostek organizacyjnych }\end{array}$ & 16 & 25 & 28 \\
\hline Radni & 7 & 2 & 3 \\
\hline Stowarzyszenia & 1 & 1 & 3 \\
\hline Przedsiębiorcy & 5 & & \\
\hline $\begin{array}{l}\text { Leszczyńskie Centrum } \\
\text { Biznesu Sp. z o.o. }\end{array}$ & 7 & 5 & 5 \\
\hline $\begin{array}{l}\text { Poznański Park Naukowo- } \\
\text {-Technologiczny Fundacji } \\
\text { Uniwersytetu im. Adama } \\
\text { Mickiewicza }\end{array}$ & 1 & & \\
\hline $\begin{array}{l}\text { Państwowa Wyższa Szkoła } \\
\text { Zawodowa w Lesznie }\end{array}$ & 4 & 2 & 3 \\
\hline Izby gospodarcze & 2 & & \\
\hline Cech & 1 & & \\
\hline Klaster & 1 & & \\
\hline Ochotnicza Straż Pożarna & & 1 & \\
\hline Państwowa Straż Pożarna & & 1 & \\
\hline $\begin{array}{l}\text { Młodzieżowa Rada Miasta, } \\
\text { Rada Seniorów }\end{array}$ & & & 2 \\
\hline $\begin{array}{l}\text { Informacja Turystyczna } \\
\text { Leszno-Region }\end{array}$ & & & 1 \\
\hline & 45 & 37 & 45 \\
\hline
\end{tabular}

Źródło: opracowanie własne na podstawie listy osób biorących udział w warsztatach zespołów roboczych [Strategia 2014, s. 9-13].

Zdaniem reprezentanta Leszna korzyści z angażowania interesariuszy w proces wyboru celów strategicznych przewyższają ewentualne niekorzyści. Dzięki udziałowi różnych grup podmiotów można poznać różne punkty widzenia, spełnić prawdziwe potrzeby i oczekiwania. Największa wada w opinii respondenta to występująca czasami trudność w dojściu do konsensusu. W jego opinii dobre współdziałanie z interesariuszami przy wyborze celów strategicznych gminy powinno rozpocząć się już na etapie analizowania danych po to, aby interesariusze byli świadomi, z czego te cele wynikają. 


\section{Zakończenie}

Tworzenie dokumentów strategicznych, w tym strategii rozwoju gmin, jest jednym z przejawów nowego zarządzania publicznego. Formułowanie celów strategicznych przy zaangażowaniu interesariuszy gmin wpisuje się w koncepcję współzarządzania.

Wybór celów strategicznych obszaru funkcjonalnego aglomeracji leszczyńskiej nastąpił przy współudziale pracowników urzędów gmin i jednostek organizacyjnych, radnych, przedstawicieli sektora prywatnego i pozarządowego, środowiska naukowego, instytucji otoczenia biznesu. Przeprowadzono badanie społeczności lokalnych (PAPI, CAWI) i zrealizowano wywiady z osobami opiniotwórczymi (IDI). Zorganizowano warsztaty z udziałem trzech zespołów roboczych (gospodarka, infrastruktura techniczna, sprawy społeczne), w trakcie których podejmowano analizę SWOT oraz wyznaczano cele strategiczne i działania o tym charakterze. Następnie odbyły się konsultacje społeczne, a projekt Strategii został zamieszczony na stronie internetowej Leszna. Można przyjąć, że proces formułowania celów strategicznych był wieloetapowy, uwzględniający realne potrzeby i oczekiwania interesariuszy gmin.

\section{Literatura}

Anders-Morawska J., Rudolf W., 2015, Orientacja rynkowa we wspótrządzeniu miastem, Wydawnictwo Uniwersytetu Łódzkiego, Łódź.

Bryson J.M., 2004, Strategic Planning for Public and Nonprofit Organizations, $3^{\text {rd }}$ edition, published by Jossey-Bass, A Wiley Imprint, San Francisco.

Bryson J.M., Alston F.K., 2005, Creating and Implementing Your Strategic Plan. A Workbook for Public and Nonprofit Organizations, $2^{\text {rd }}$ edition, published by Jossey-Bass, A Wiley Imprint, San Francisco.

Cyfert S., Krzakiewicz K., 2017, Wprowadzenie do nauki o organizacji, Wydawnictwo UEP, Poznań.

Flieger M., 2016, Optymalizacja funkcjonowania instytucji administracji publicznej poprzez kooperacje w sieci, Prace Naukowe Uniwersytetu Ekonomicznego we Wrocławiu, nr 421, s. 114-127.

Frączkiewicz-Wronka A., 2012, Rola i znaczenie interesariuszy w procesie podejmowania decyzji $w$ organizacjach publicznych, [w:] Frączkiewicz-Wronka A. (red.), Wykorzystanie analizy interesariuszy w zarządzaniu organizacja zdrowotna, Śląsk Sp. z o.o. Wydawnictwo Naukowe, Katowice, s. 15-45.

Gawroński H., 2010, Zarządzanie strategiczne w samorzadach lokalnych, Oficyna a Wolters Kluwer business, Warszawa.

Koncepcja Przestrzennego Zagospodarowania Kraju 2030, 2011.

Kulesza M., Sześciło D., 2013, Polityka administracyjna i zarządzanie publiczne, Lex a Wolters Kluwer business, Warszawa.

Lachiewicz S., Walecka A., 2013, Organizacje publiczne i pozarządowe, [w:] Adamik, A. (red.), Nauka o organizacji, Oficyna a Wolters Kluwer business, Warszawa.

Obłój K., Strategia organizacji, Polskie Wydawnictwo Ekonomiczne, Warszawa.

Potkański T., Wiktorczyk-Nadolna, A. (red.), 2016, Rozwój wspótpracy międzysamorządowej i międzysektorowej w Polsce. Doświadczenia Projektu Predefiniowanego „,Budowanie kompetencji do wspótpracy międzysamorzadowej i międzysektorowej jako narzędzia rozwoju lokalnego i regionalnego" w latach 2012-2016, Drukarnia Empir, Poznań.

Strategia Rozwoju Spoteczno-Gospodarczego Obszaru Funkcjonalnego Aglomeracji Leszczyńskiej do 2030 roku, 2014, Leszno.

Zawicki M., 2011, Nowe zarzadzanie publiczne, Polskie Wydawnictwo Ekonomiczne, Warszawa. 